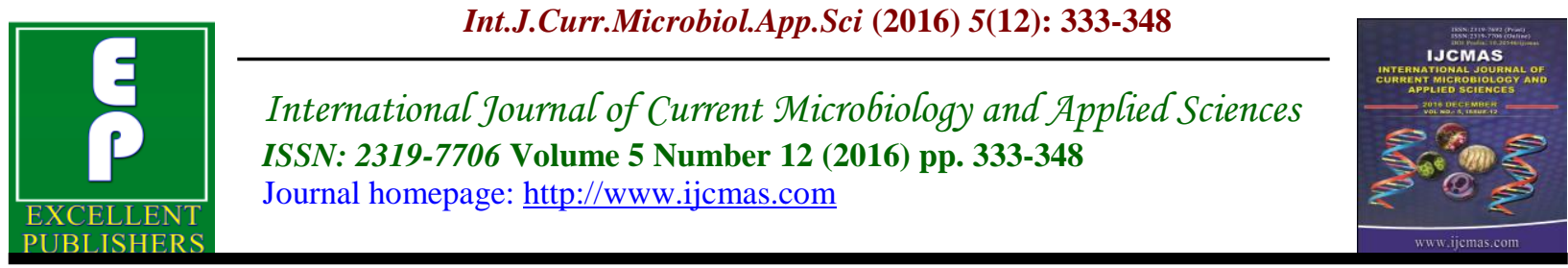

Original Research Article

http://dx.doi.org/10.20546/ijcmas.2016.512.036

\title{
Sensory Attributes and Physicochemical Characteristics of Cultured Buttermilk prepared by Partial Substitution of Milk with Paneer Whey
}

\author{
Sonali L. Parekh*, Smitha Balakrishnan and K.D. Aparnathi
}

Department of Dairy Chemistry, SMC College of Dairy Science, Anand

Agricultural University, Anand-388110, India

*Corresponding author

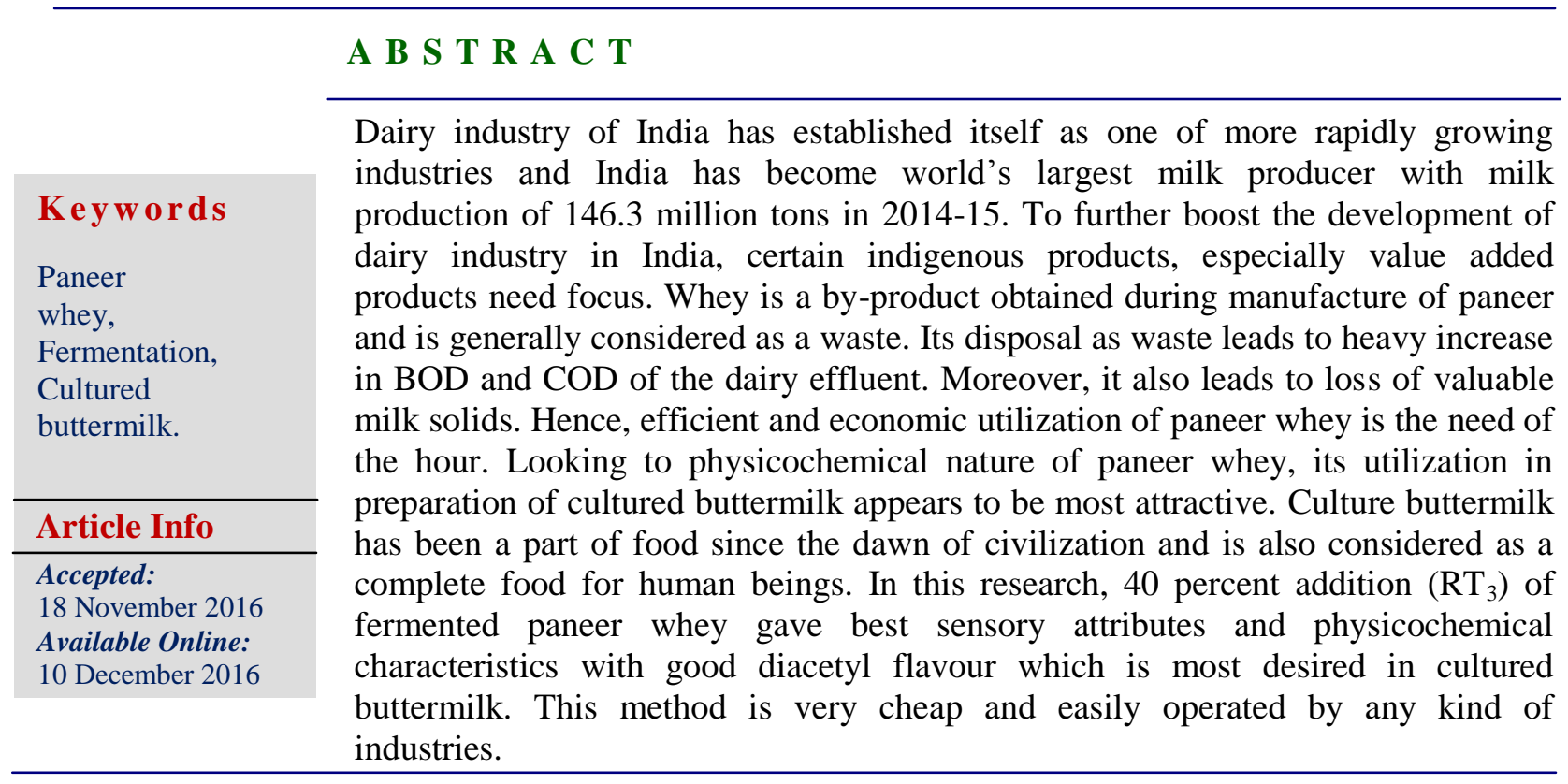

\section{Introduction}

Whey is considered as gold if it is properly and efficiently utilized. However, if it is drain as a waste it creates serious nuisance. The bottleneck in utilization of whey is its dilute nature which required handling of large volume. Membrane techniques have been developed for efficient utilization of whey, but due to very huge investment requirement small and medium scale producer cannot afford for it. Therefore development of very simple technology for utilization of whey is expected by the industries.
Looking to the physicochemical nature of the paneer whey, it appears highly promising for its utilization in manufacture of cultured buttermilk. Normally, three types of buttermilk are produced in our country, viz. (a) sweet cream buttermilk (SCBM), which is obtained by churning of fresh/pasteurized cream with little or no developed acidity, (b) sour buttermilk, which is obtained by churning of naturally sour milk or cream, and (c) desi buttermilk (chhachh or lassi), which is obtained by churning of curd (dahi) during the 
manufacture of makhkhan (Pal and Raju, 2008). Paneer whey being a watery byproduct of milk, it has potential to serve as an excellent substitute of water in preparation of cultured buttermilk from curd.

Traditional as well as cultured buttermilk has remained as an excellent source of nutrition as it consists of good amounts of potassium, phosphorus, vitamin $\mathrm{B}_{12}$, riboflavin, enzymes, protein, and calcium (Conway et al., 2014). Buttermilk has wide food applications and can be used for drinking purposes; it may be supplemented to produce sour cream or cultured butter. Buttermilk is often used in baking because of its special properties (for instance, sourness, enzymes, and microflora present in this byproduct).

It can enhance the flavour of various preparations like dips and cakes. Further, buttermilk can be used as a battering agent for frying of chops of pork and chicken (Shukla et al., 2004). Various studies have also shown the therapeutic importance of the consumption of buttermilk (Larsson et al., 2008; Conway et al., 2013; Fuller et al., 2013; Fu et al., 2014).

In previous work carried out at this laboratory method was standardized for preparation of cultured buttermilk by partial substitution with paneer whey (Maheta et al., 2015). In present study, work is carried out to evaluate the cultured buttermilk with modification in use of cultures prepared by partial substitution of milk with paneer whey for its sensory attributes and physicochemical characteristics.

\section{Materials and Methods}

Cultured buttermilk was prepared according to the method described by Maheta et al. (2015).
Evaluation of different modes to incorporate paneer whey in buttermilk

Different approaches were evaluated for the incorporation of paneer whey in the preparation of cultured buttermilk as described below.

i. Dahi prepared from double toned milk was blended with non-fermented paneer whey

ii. Dahi prepared from double toned milk was blended with fermented paneer whey

iii. Fermentation of double toned milk and paneer whey blend for preparation of dahi and finally buttermilk

The starter cultures, $S$. thermophilus MTCC 5460 and $L b$. helveticus MTCC 5463 were used for fermentation during this phase of studies. Dahi and non-fermented and fermented paneer whey were blended in the ratio of 70:30. Buttermilk obtained without addition of paneer whey was used as control. The mode of incorporation of paneer whey which gave buttermilk with best sensory characteristics was selected for screening of starter cultures.

Screening of starter cultures for the preparation of cultured buttermilk

The active strains of starter culture Streptococcus thermophilus MTCC 5460, Lactobacillus helveticus MTCC 5463, Lactococcus lactis sub spp lactis NCDC 193, Lactococcus lactis subspp. diacetylactis NCDC 60 were used singly and in combinations to evaluate their suitability in making dahi, intended for the preparation of cultured buttermilk. The curd was prepared by employing above mentioned starter cultures at the rate of 2 per cent by using 
selected mode of incorporation of paneer whey.

\section{Optimization of rate of addition of whey}

Suitability of addition of fermented paneer whey to dahi in three different rates like 30, 40, 50 and 60 per cent (w/w) was studied.

\section{Incubation}

The double toned milk inoculated with starter culture was filled in cleaned and sanitized glass beakers, which were covered with aluminium foil. The incubation was carried at $37 \pm 2{ }^{\circ} \mathrm{C}$ for $6 \mathrm{~h}$ or till desired acidity in the curd (i.e 0.67 per cent lactic acid) was obtained.

\section{Physicochemical characteristics}

Total solids and titratable acidity of the double toned milk was measured as per the BIS method (BIS, 1981). Diacetyl production in cultured buttermilk was measured by creatine test method suggested by Yadav et al., (1993).Viscosity of cultured buttermilk was determined by using 'Brook field' viscometer (DV II + Pro Viscometer, Model- LVDV- II + P, USA)

\section{Sensory characteristics}

The buttermilk samples packed in PET bottles and stored at $7 \pm 1^{\circ} \mathrm{C}$ were evaluated for their sensory using 9-point hedonic score card.

\section{Statistical analysis}

Statistical analysis of data was carried out by applying completely randomized design (CRD) (Steel and Torrie, 1980).

\section{Results and Discussion}

\section{Selection of mode of addition of whey}

It was evident from the Table 1 that fermenting paneer whey and milk separately, followed by addition of the fermented paneer whey in to the dahi $\left(\mathrm{T}_{3}\right)$ yielded the cultured buttermilk with the highest flavour scores amongst all the samples and it differed significantly $(\mathrm{P}<$ 0.05) from other treatments. Fermentation had eliminated the adverse effect of paneer whey on flavor mainly the typical whey flavour on cultured buttermilk.

Paneer whey contains higher amount of citrate $(6750 \mathrm{mg} / \mathrm{l})$ and this citrate is metabolize in to different flavor components by fermentation. On the other hand difference in the flavor score of $\mathrm{T}_{1}$ (Prepared by blending dahi with untreated paneer whey) and $\mathrm{T}_{2}$ (Prepared by fermenting milk and paneer whey blend) was not siginificant and was comparatively less than $\mathrm{T}_{3}$. Among all treatments the lowest score was for control and the reason can be attributed to presence of water resulting in dilution of flavor compounds.

Prado et al., (2008) found that the fermentation of paneer whey using lactic starters gave the pleasant taste and flavored product.

Walstra et al., (2005) reported that lactic acid bacteria used as dairy starter cultures perform a number of important functions in fermented milk products, in addition to production of lactic acid from lactose by fermentation. One of the most important functions amongst these is to produce several flavor compounds like diacetyl. The diacetyl is responsible for the desirable buttery flavor attributes in fermented dairy products like cultured buttermilk, cultured butter, yoghurt, some ripened variety of cheeses, etc. Diacetyl, at a concentration of 2 to $5 \mathrm{mg} / \mathrm{kg}$, is responsible for the characteristic aromatic flavor of cultured buttermilk. Therefore, results obtained in present study are in general agreement with 
those reported in the literature and the buttermilk $T_{3}$ prepared by the mode of addition of fermented whey to dahi was judged as the best based on flavour score.

Cultured buttermilk $\mathrm{T}_{3}$ prepared by blending dahi with fermented paneer whey scored highest for colour and appearance (8.36) followed by $\mathrm{T}_{2}(8.15)$ and $\mathrm{T}_{1}(7.98)$. The difference in the scores among the cultured buttermilks prepared by various modes of incorporation of paneer whey was nonsignificant for colour and appearance but they differed significantly from $\mathrm{T}_{4}$. Colour and appearance score of the control cultured buttermilk $\mathrm{T}_{4}$ (7.55) was lowest among all cultured buttermilk samples. Addition of water diluted the total content of the dahi and gave watery appearance to the product, which inturn caused lowering of colour and appearance score of the product.

The paneer whey used in the present study contained on an average 5.96 per cent total solid. Therefore, incorporation of paneer whey into cultured buttermilk in place of water contributed to total solids content of the resultant cultured buttermilk, which in turn improved the colour and appearance score of the product. The slight improvement in colour and appearance of cultured buttermilk due to fermentation of paneer whey may be attributed physicochemical changes taking place in components of paneer whey.

Jinjarak et al., (2005) reported that whey buttermilk (WBM) had similar sensory characteristics as regular sweet cream buttermilk (SCBM); however, there was a marked colour difference between them. WBM was significantly more yellow than the SCBM samples. Colour of raw paneer whey is generally slightly greenish due to the presence of riboflavin and no colour difference can be observed by fermentation of paneer whey (Gallardo-Escamilla et al., 2005).

But in this study addition of milk solids in the form of fermented or unfermented whey into the buttermilk ( $T_{1}, T_{2}$ and $T_{3}$ ) resulted in better colour and appearance of the product compared to control sample $\mathrm{T}_{4}$. Riboflavin present in whey could also be contributing to colour.

Body and texture score of $\mathrm{T}_{3}$ prepared by blending dahi with fermented paneer whey scored highest for body and texture (8.38) followed by $\mathrm{T}_{2}$ (7.88) and $\mathrm{T}_{1}$ (7.68). Body and texture score of the control cultured buttermilk $\left(\mathrm{T}_{4}\right)$ was lowest (6.60) compared to the samples of cultured buttermilk obtained by addition of paneer whey either fermented or unfermented. In case of control cultured buttermilk, water was blended to dahi for preparation of cultured buttermilk. This addition of water diluted the total solid content of the curd, which in turn caused lowering of body and texture score of the product. In case of cultured buttermilk from unfermented paneer whey, the typical flavour and physiological changes of paneer whey prevailed because was not subjecting to fermentation.

Some LAB starter strains produce high amounts of low calorie polyols having fibre like nature, and bifidogenic effect. LAB starter cultures producing exopolysachharide in-situ during milk fermentation have found application as a natural source of food bio thickeners (e.g., yoghurt and Scandinavian fermented milk villi). Approximately 30 species of LAB produce EPS and the best known are Lb.casei, Lb. acidophilus, Lb. brevis, Lb. curvatus, Lb. helveticus, $L b$. rhamnosus and Lb. plantarum (Mollea et al., 2013). Lactobacillus helveticus MTCC 5463 used as starter in this phase of study also has EPS producing quality and that 
improved the body and texture profile of the cultured buttermilk and gave better consistency to the buttermilk.

Therefore, results obtained in present study are in general agreement with those reported in the literature and the buttermilk $\mathrm{T}_{3}$ prepared by the mode of addition of fermented whey in to dahi was judged as the best based on body and texture.

The cultured buttermilk prepared by addition of fermented paneer whey to dahi $\left(\mathrm{T}_{3}\right)$ gave highest overall acceptability scores and it differed significantly $(\mathrm{P}<0.05)$ from all the samples. On the other hand, the difference in the overall acceptability score of cultured buttermilk prepared by addition of unfermented paneer whey to dahi $\left(\mathrm{T}_{1}\right)$ and by fermenting milk and paneer whey blend was non-significant and was less than that of $\mathrm{T}_{3}$. The lowest score was for control sample $\left(\mathrm{T}_{4}\right)$.

Landge and Gaikwad (2013) prepared whey beverage from channa or paneer whey (14 per cent sugar with pinch of jeera) was most acceptable.

Lactose is largely removed in the whey during paneer making. Development of acid from lactose by culture is the first controlling factor in the manufacture of fermented dairy products. Therefore, titratable acidity is one of the most important points of concern for fermented dairy products. Results for analysis of titratable acidity of samples of cultured buttermilk prepared by different mode of addition of paneer whey are presented in Table 2.

It is evident from the data that the mode of addition of paneer whey in preparation of cultured buttermilk has a significant effect on acidity of the cultured buttermilk.
The acidity values were lowest in case of control cultured buttermilk $\left(\mathrm{T}_{4}\right)$ due to the dilution effect by addition of water, followed by the sample of cultured buttermilk prepared by addition of unfermented paneer whey $\left(\mathrm{T}_{1}\right)$ or by fermenting milk and paneer whey blend $\left(\mathrm{T}_{2}\right)$. The highest acidity was observed for $\mathrm{T}_{3}(0.61)$ and it differed significantly from other treatments. Addition of whey in all treatments lead to increased acidity compared to the control. This can be attributed to acidity of paneer whey itself (paneer whey used in this study has average acidity of 0.19 per cent lactic acid) and also to the additional acidity developed by fermentation of lactose present in whey (approximately 4.60 per cent lactose is present in paneer whey).

Almeida et al., (2009) carried out the study on total solids content of paneer whey on acidifying profile of various lactic acid bacteria. The authors found that addition of total milk solids increases the rate of acid production in the paneer whey beverages. Thus, the acidity values of various samples of cultured buttermilk prepared in the present studies are in general agreement with those reported in the literature.

Alsaed and Ahmed (2010) studied the characterization, concentration and utilization of sweet and acid whey. They found that the concentrated acid whey (CAW) has more acidity (4.95 per cent) compared with the concentrated sweet whey.

From the first phase study, it was concluded that cultured buttermilk $\mathrm{T}_{3}$ prepared by blending dahi and fermented paneer whey was found to have most acceptable sensory attributes like flavor, body and texture and overall acceptability. The rate of acidity development was also satisfactory in the $T_{3}$ type of cultured buttermilk. Therefore, for 
preparation of cultured buttermilk, addition of fermented paneer whey to dahi was selected as the best mode for incorporation of paneer whey and further studies were conducted with such a mode of preparation.

\section{Selection of starter cultures}

In manufacture of fermented and cultured dairy products, the process is based on activity of the starter culture employed. Therefore, selection of most appropriate culture in preparation of fermented and cultured dairy products is very crucial.

Lactic starter cultures may consist of single strains used alone or in combinations or undefined mixtures of strains (mixed-strain cultures). According to their optimal growth temperature, two classes of lactic acid bacteria are normally used for the preparation of fermented milks: mesophilics and thermophilics. The mesophilics (strains of Lactococcus lactis subspecies lactis biovariety diacetylactis and some species belonging to Leuconostoc genera) are good aroma producers, but not very acidifying. These have an optimum growth temperature between $20^{\circ}$ and $30^{\circ} \mathrm{C}$. Apart from the production of lactic acid, certain cultures also produce diacetyl. These are widely used in the making of dahi, culture buttermilk, butter, lassi, etc. (Behare et al., 2015).

In this second phase of this study, cultures were screened on the basis of their performance i.e. sensory characteristic of the resultant product i.e. cultured buttermilk and the desired acidity in the product. Cultures were used singly and in combination to study their suitability in the preparation of cultured buttermilk.

The active strains of starter culture $S$. thermophilus MTCC 5460, Lb. helveticus MTCC 5463, L. lactis subspp. lactis NCDC 193 and L. lactis subspp. diacetylactis
NCDC 60were used singly and in combinations to evaluate their suitability in making dahi and ferment paneer whey, intended for the preparation of cultured buttermilk. From preliminary studies on growth curve of starters singly and in combination, it was found that combination of mesophilic cultures L. lactis subspp. lactis NCDC 193, L. lactis subspp. diacetylactis NCDC 60 along with themophilic Lb. helveticus MTCC 5463 gave promising results. Neither proper growth nor sufficient acidity was developed in case of combination of $S$. thermophilus MTCC 5460 and above mesophilic strains. So only selected combination of mesophilic and thermophilic cultures was included in the study. The results of evaluation of sensory characteristics of cultured buttermilk prepared using different starter cultures are presented in Table 3.

In case of individual cultures buttermilk prepared using Lb. helveticus MTCC 5463 and S. thermophilus MTCC 5460 showed better scores as compared to that prepared using L. lactis subspp. diacetylactis NCDC 60 and L. lactis subspp. Lactis NCDC 193. The highest flavor score was for buttermilk prepared using combination of cultures $L b$. helveticus MTCC 5463 and L. lactis subspp. diacetylactis NCDC 60 in 1:1 ratio and it differed significantly $(\mathrm{P}<0.05)$ from all other samples. The reason for better flavor of $\mathrm{S}_{6}$ can be correlated to high proteolytic activity of Lb. helveticus MTCC 5463 and to the diacetly production by $L$. lactis subspp. diacetylactis NCDC 60.

Lactococcus lactis is widely applied for the acidification and proteolysis in milk fermentation and cheese manufacturing. The L. lactis subspp. lactis. diacetylactis is incorporated into starter cultures for diacetyl aroma development(Oliveira et al., 2009; Pogačić et al., 2013). 
The second highest flavour score of buttermilk was for $\mathrm{S}_{5}$ prepared using mixed culture of $S$. thermophilus MTCC 5460 and Lb. helveticus MTCC 5463. These strains being good acid produced gave better flavor by masking the typical flavor of raw panner whey. Also the proteolytic action of these strains have added to better flavor development.

The poor performance of alone L. lactis subspp. diacetylactis NCDC 60 and L. lactis subspp. lactis NCDC 193 in flavour score of cultured buttermilk may be attributed to its lower acid production and its low proteolytic activity thereby unable to completely mask the typical paneer whey flavour. It had become evident from the data that the use of combination of starter culture in preparation of cultured butter milk along with paneer whey resulted into the product with improved flavour scores.

It is evident from the Table 3 that cultured buttermilk prepared by fermentation using single cultures of Streptococcus thermophilus MTCC 5460 and $L b$. helveticus MTCC 5463 as well as combination of cultures Lb. helveticus MTCC 5463and L. lactis subspp. diacetylactis NCDC 60 gave scores above 8.5 for colour and appearance score and difference among them was not statistically non-significant. The relatively better colour and appearance scores of cultured buttermilk prepared using $L b$. helveticus may be attributed to its ability to produce exopolysaccharide (EPS) and ability to give smooth appearance to the product (Pescuma et al., 2008).

The buttermilk prepared using single cultures of $L b$. helveticus MTCC 5463( $\left.\mathrm{S}_{2}\right)$ scored highest for body and texture and it differed significantly $(\mathrm{P}<0.05)$ from all other butter milk except $S_{6}$. The cultured buttermilk $\mathrm{S}_{2}, \mathrm{~S}_{5}$ and $\mathrm{S}_{6}$ whose score for body and texture were better compared to others were prepared using starter culture Lb. helveticus MTCC 5463 singly and in combination with $S$. thermophiles MTCC 5460 and L. lactis subspp. diacetylactis NCDC 60 respectively.

In general, milk curdling and gelation are normally initiated by a $\mathrm{pH}$ value below 5.5. Casein micelles destabilize and the protein matrix irreversibly precipitates. At this $\mathrm{pH}$ value, LAB produce adequate amounts of EPS and influence the gelation process. Scanning electron and confocal scanning laser microscopy approaches nicely illustrate the network of bacterial carbohydrate chains and globular milk protein (Ayala-Hernandez et al., 2008). Charged and hydrophobic sides of EPS intercalate into the milk protein matrix and affect texture formation (Hassan, 2008; Jolly et al., 2002).

Overall acceptability scores of the cultured buttermilk prepared using combination of cultures Lb. helveticus MTCC 5463 and L.lactis subspp. diacetylactis NCDC 60 in 1:1 ratio were the highest and it differed significantly $(\mathrm{P}<0.05)$ from all other cultured buttermilk samples. The relatively better overall acceptability scores of cultured buttermilk prepared using Lactobacillus helveticus MTCC5463 and L. lactis subspp. diacetylactis NCDC 60 is due to specific activity of these cultures. Lactobacillus helveticus MTCC 5463 is a strain with established proteolytic activity (Shah, 2003), which has contributed to desirable flavour characteristic. The Lactococcus lactis subspp diacetylactis NCDC 60 strain obtained from National Collection of Dairy Culture (NCDC), NDRI, Karnal is heterofermentative and it has the ability to utilize citrate and produces carbon dioxide, diacetyl, volatile fatty acids and acetoin (Behare et al., 2009). 
The physicochemical characteristics of buttermilk prepared by blending dahi with fermented paneer whey using different starter cultures are presented in the Table 4.

The acidity value was highest in case of cultured buttermilk $\mathrm{S}_{5}$ (0.74) obtained by fermentation using combined starter cultures of S. thermophiles MTCC 5460 and Lb. helveticus MTCC 5463 and they differed significantly from all other experimental samples except $S_{2}(0.72$ per cent lactic acid) and $S_{7}$ (0.70 per cent lactic acid). The high acidity in $\mathrm{S}_{5}$ was due to $S$. thermophiles MTCC 5460. They are acid tolerant, generally fastidious, requiring simple carbohydrates as energy source, and preformed amino acids as nitrogen source. It ferments lactose homofermentatively to give $\mathrm{L}(+)$ lactic acid as the principal product.

S. thermophilus MTCC 5460 along with probiotic organism Lb. helveticus MTCC 5463 was used to manufacture probiotic lassi (Patidar and Prajapati, 1998).

Almaida et al., (2008) reported that the shortest fermentation time to reach $\mathrm{pH} 4.5$ was obtained with co-cultures $S$. thermophilus and Lb. delbrueckii subspp. bulgaricus $(5.26 \mathrm{~h})$, followed by $S$. thermophilus and B. animalis subspp. lactis $(6.78 \mathrm{~h}), \quad S$. thermophilus and Lb. acidophilus $(7.13 \mathrm{~h})$, and $S$. thermophilus and Lb. rhamnosus $(12.40 \mathrm{~h})$. However, Oliveira and Damin (2003) reported different fermentation times for co-cultures $S$. thermophilus and Lb. delbrueckii subspp. bulgaricus, and $S$. thermophilus and $L b$. rhamnosus grown in milk until $\mathrm{pH} 4.5$ (i.e. $7.9,12.5$, and $7.3 \mathrm{~h}$, respectively). In addition, the fermentation time of the probiotic co-culture $S$. thermophilus and $L b$. acidophiluswas $8.8 \mathrm{~h}$ which was faster than using co-culture $S$. thermophilus and $L b$. rhamnosus (13.2 h). These reports reveal that the time required to achieve desired acidity varies with type of cultures used. Therefore, results obtained in the present study regarding development acidity were in general agreement with those reported in the literature.

Viscosity of $\mathrm{S}_{2}$ and $\mathrm{S}_{5}$ buttermilk containing single strain of Streptococcus thermophilus MTCC 5460 and mixed culture of Streptococcus thermophilus MTCC 5460 and Lactobacillus helveticus MTCC 5463 (in 1:1 ratio)was 162.33 and $157.00 \mathrm{cp}$ respectively at $20^{\circ} \mathrm{C}$ which was higher than that for other samples and the difference was non-significant. The $\mathrm{S}_{6}$ prepared using mixed cultures of Lactobacillus helveticus MTCC 5463 and Lactococcus lactis subspp. diacetylactis NCDC 60 (in 1:1 ratio) also had highest viscosity (136.33) in comparison to rest of experimental smaples. The highest viscosity of these samples is due the ability of Lactobacillus helveticus MTCC 5463 to produce exo-polysaccharide (EPS) (Pescuma et al., 2008; Shah, 2003).

The creatine test for diacetyl production gave positive result for $S_{3}, S_{4}, S_{6}$ and $S_{7}$ resulting since these buttermilk samples contained Lactococcus lactis subspp. diacetylactis NCDC 60 and Lactococcus lactis subspp. lactis NCDC 193 either singly or in combination.

Results of the work carried out for screening of starter cultures to prepare cultured butter milk along with paneer whey indicated that the combination of starter cultures gave the best results compared to single starter cultures. Therefore, based on sensory characteristics and desired acidity in the final product amongst all starter cultures evaluated $L b$. helveticus MTCC 5463 and $L$. lactis subspp. diacetylactis NCDC 60 combination was selected for further studies. 


\section{Optimization for amount of fermented paneer whey}

Four types of buttermilk $\mathrm{RT}_{1}$ ( 60 per cent of fermented whey), $\mathrm{RT}_{2}$ (50 per cent of fermented whey), $\mathrm{RT}_{3}$ (40 per cent of fermented whey) and $\mathrm{RT}_{4}$ (30 per cent of fermented whey) were analyzed for their sensory and physicochemical characteristics. The results along with their statistical analysis are presented in Table 5 and 6 . The $\mathrm{RT}_{5}$, the buttermilk obtained by blending dahi and water in the ratio of 70:30 (control) and $\mathrm{RT}_{6}$, a market sample of buttermilk were also analyzed for their sensory characteristics along with the experimental samples.

From the data it can be seen that the maximum flavour score of the cultured buttermilk is for $\mathrm{RT}_{4}$ (8.12) obtained by addition of paneer whey at the rate of 30 per cent and it differed significantly $(\mathrm{P}<0.05)$ from all other samples except $\mathrm{RT}_{3}$. The minimum flavour score of the cultured buttermilk was obtained for market sample. No data are reported in the literature regarding effect of amount of fermented paneer whey incorporated in the buttermilk on flavour score of the resultant cultured buttermilk or other similar cultured dairy products.

It is evident from the Table. 5 that the flavor scores decreased with increase in rate of addition of fermented whey. The flavor scores of $\mathrm{RT}_{3}$ (7.75) and $\mathrm{RT}_{4}$ (8.12) differed non-significantly and both differed significantly from other experimental samples. The better flavor of $\mathrm{RT}_{3}(60: 40)$ and $\mathrm{RT}_{4}(70: 30)$ can be correlated to their higher total solids and optimum presence of flavor components contributed by fermented whey. Although $\mathrm{RT}_{5}$ (control, 70: 30, dahi: water) has more TS compared to $\mathrm{RT}_{3}$ its flavor score is less compared to $\mathrm{RT}_{3}$ as the former lacks in flavor components from fermented whey.

From the data it can be seen that the maximum colour and appearance score of the cultured buttermilk was obtained on addition of paneer whey at the rate of 30 per cent. The minimum colour and appearance score of the cultured buttermilk was obtained from market sample.

Body and texture is an important attribute in determining the acceptability of a product on visual perception. From the data it can be seen that the body and texture scores of the cultured buttermilk $\mathrm{RT}_{3}$ and $\mathrm{RT}_{4}$ obtained on addition of paneer whey at the rate of 30 and 40 per cent, respectively were higher and they differed significantly $(\mathrm{P}<0.05)$ from other samples. The minimum body and texture score of the cultured buttermilk was obtained for market sample $\left(\mathrm{RT}_{6}\right)$. Better body and texture of $\mathrm{RT}_{3}$ and $\mathrm{RT}_{4}$ can be correlated with higher milk solids in these buttermilks as they contained more proportion of dahi (60 and 70 per cent, respectively) compared to others.

The overall acceptability generally goes parallel with the flavour and body and texture scores in case of buttermilk. From the data, it can be seen that the maximum overall acceptability score was for cultured buttermilk prepared by the addition of 40 and 30 per cent of fermented paneer whey i.e. for $\mathrm{RT}_{3}$ and $\mathrm{RT}_{4}$, respectively and the difference among them was non-significant. The minimum overall acceptability score of the cultured buttermilk was for market sample $\left(\mathrm{RT}_{6}\right) \cdot \mathrm{RT}_{3}$ and $\mathrm{RT}_{4}$ had better flavor as well as body and texture compared to other experimental samples as evident from Table 5. This is due to the presence of more milk solids and their contribution to flavor as well as body and texture. 
Table.1 Effect of mode of addition of paneer whey on sensory profile of cultured buttermilk

\begin{tabular}{|c|c|c|c|c|}
\hline \multirow{2}{*}{$\begin{array}{c}\text { Mode of } \\
\text { addition of } \\
\text { paneer whey }\end{array}$} & \multicolumn{4}{|c|}{ Sensory score } \\
\hline & Flavour & $\begin{array}{l}\text { Colour and } \\
\text { appearance }\end{array}$ & $\begin{array}{c}\text { Body and } \\
\text { texture }\end{array}$ & $\begin{array}{c}\text { Overall } \\
\text { acceptability }\end{array}$ \\
\hline $\mathrm{T}_{1}$ & $7.73^{\mathrm{a}}$ & $7.98^{\mathrm{bc}}$ & $7.68^{\mathrm{a}}$ & $7.72^{\mathrm{a}}$ \\
\hline $\mathrm{T}_{2}$ & $7.90^{\mathrm{a}}$ & $8.15^{\mathrm{c}}$ & $7.88^{\mathrm{a}}$ & $7.80^{\mathrm{a}}$ \\
\hline$T_{3}$ & $8.60^{b}$ & $8.36^{\mathrm{c}}$ & $8.38^{\mathrm{b}}$ & $8.58^{\mathrm{b}}$ \\
\hline $\mathrm{T}_{4}$ & $6.35^{\mathrm{c}}$ & $7.55^{\mathrm{b}}$ & $6.60^{c}$ & $6.65^{\mathrm{c}}$ \\
\hline SEm \pm & 0.14 & 0.15 & 0.09 & 0.16 \\
\hline CD & 0.44 & 0.47 & 0.28 & 0.50 \\
\hline CV \% & 3.77 & 3.77 & 2.40 & 4.22 \\
\hline \multicolumn{5}{|c|}{$\begin{array}{l}\mathrm{T}_{1}: \text { Prepared by blending dahi with unfermented paneer whey in } 70: 30 \mathrm{w} / \mathrm{w} \text { ratio } \\
\mathrm{T}_{2}: \text { Prepared by fermenting blend of milk and paneer whey in } 70: 30 \mathrm{w} / \mathrm{w} \text { ratio } \\
\mathrm{T}_{3}: \text { Prepared by blending dahi with fermented paneer whey in } 70: 30 \mathrm{w} / \mathrm{w} \text { ratio } \\
\mathrm{T}_{4}: \text { Prepared by blending dahi with water in } 70: 30 \mathrm{w} / \mathrm{w} \text { ratio (control) } \\
\text { \# The values are means of four replications. } \\
\text { ** Values within columns (treatments) with same lowercase superscript did not differ } \\
\text { significantly }(\mathrm{P}<0.05) \text { from each other. }\end{array}$} \\
\hline
\end{tabular}

Table.2 Effect of mode of addition of paneer whey on titratable acidity of cultured buttermilk

\begin{tabular}{|c|c|}
\hline Mode of addition of paneer whey & Titratable acidity (\% lactic acid) \\
\hline $\mathrm{T}_{1}$ & $0.56^{\mathrm{a}}$ \\
\hline $\mathbf{T}_{2}$ & $0.57^{\mathrm{a}}$ \\
\hline $\mathbf{T}_{3}$ & $0.61^{\mathrm{c}}$ \\
\hline $\mathbf{T}_{4}$ & $0.54^{\mathrm{b}}$ \\
\hline SEm \pm & 0.01 \\
\hline CD & 0.01 \\
\hline CV\% & 1.03 \\
\hline \multicolumn{2}{|c|}{$\begin{array}{l}* \mathrm{~T}_{1} \text { : Prepared by blending dahi with unfermented paneer whey } \\
\mathrm{T}_{2} \text { : Prepared by fermenting milk and paneer whey blend } \\
\mathrm{T}_{3} \text { : Prepared by blending dahi with fermented paneer whey } \\
\mathrm{T}_{4} \text { : Prepared by blending dahi with water (control) } \\
\text { \# The values are means of four replications. } \\
\text { ** Values within columns (treatments) with same lowercase superscript did not differ } \\
\text { significantly }(\mathrm{P}<0.05) \text { from each other. }\end{array}$} \\
\hline
\end{tabular}


Table.3 Effect of type of starter cultures on sensory profile of cultured buttermilk

\begin{tabular}{|c|c|c|c|c|}
\hline \multirow{2}{*}{$\begin{array}{l}\text { Type of } \\
\text { Starter } \\
\text { cultures }\end{array}$} & \multicolumn{4}{|c|}{ Sensory score } \\
\hline & Flavour & $\begin{array}{l}\text { Colour and } \\
\text { appearance }\end{array}$ & Body and texture & $\begin{array}{c}\text { Overall } \\
\text { acceptability }\end{array}$ \\
\hline $\mathrm{S}_{1}$ & $7.17^{\mathrm{bc}}$ & $8.67^{\mathrm{a}}$ & $7.92^{\mathrm{cd}}$ & $8.00^{\mathrm{cb}}$ \\
\hline $\mathrm{S}_{2}$ & $7.25^{\mathrm{bc}}$ & $8.50^{\mathrm{ab}}$ & $8.67^{\mathrm{a}}$ & $7.80^{\mathrm{cb}}$ \\
\hline $\mathrm{S}_{3}$ & $5.17^{\mathrm{d}}$ & $7.83^{\mathrm{c}}$ & $6.67^{\mathrm{e}}$ & $6.36^{\mathrm{a}}$ \\
\hline $\mathrm{S}_{4}$ & $5.00^{\mathrm{d}}$ & $8.00^{b}$ & $6.50^{\mathrm{e}}$ & $6.29^{\mathrm{a}}$ \\
\hline $\mathrm{S}_{5}$ & $8.22^{\mathrm{a}}$ & $8.67^{\mathrm{a}}$ & $8.16^{\mathrm{bc}}$ & $8.20^{\mathrm{c}}$ \\
\hline $\mathrm{S}_{6}$ & $8.85^{\mathrm{a}}$ & $8.75^{\mathrm{a}}$ & $8.58^{\mathrm{ab}}$ & $8.78+{ }^{\mathrm{d}}$ \\
\hline $\mathrm{S}_{7}$ & $6.67^{\mathrm{b}}$ & $8.00^{\mathrm{b}}$ & $7.98^{\mathrm{cd}}$ & $7.07^{\mathrm{e}}$ \\
\hline SEm \pm & 0.20 & 0.21 & 0.14 & 0.18 \\
\hline $\mathrm{CD}$ & 0.60 & 0.64 & 0.42 & 0.53 \\
\hline $\mathrm{CV} \%$ & 4.96 & 4.39 & 3.06 & 4.05 \\
\hline $\begin{array}{l}{ }^{*} \mathrm{~S}_{1}: \text { Strep } \\
\mathrm{S}_{2}: \text { Lactob } \\
\mathrm{S}_{3} \text { : Lactoc } \\
\mathrm{S}_{4} \text { : Lactoc } \\
\mathrm{S}_{5}: \text { Strepto } \\
\text { Lactobacil } \\
\mathrm{S}_{6}: \text { Lactob } \\
\text { Lactococc } \\
\mathrm{S}_{7}: \text { Lactob } \\
\text { Lactococc } \\
\text { \# The valu } \\
\text { ** Values } \\
\text { significant }\end{array}$ & $\begin{array}{l}\text { us thermo } \\
\text { helveticu } \\
\text { actis sub } \\
\text { lactis sub } \\
\text { thermop } \\
\text { lveticus } \mathrm{M} \\
\text { helveticu } \\
\text { is subspp. } \\
\text { helveticu } \\
\text { is subspp. } \\
\text { mean of } \mathrm{t} \\
\text { column } \\
\text { 0.05) fron }\end{array}$ & $\begin{array}{l}\text { TCC } 5460 \\
5463 \\
\text { etylactis NCD } \\
\text { NCDC } 193 \\
\text { CC } 5460 \text { and } \\
63 \text { (in } 1: 1 \text { ratic } \\
5463 \text { and } \\
\text { actis NCDC } 6 \\
5463 \text { and } \\
\text { CDC } 193 \text { (in } 1 \\
\text { ications. } \\
\text { ts) with same } \\
\text { ner. }\end{array}$ & case superscript d & differ \\
\hline
\end{tabular}

Table.4 Effect of starter cultures on physicochemical characteristics of cultured buttermilk

\begin{tabular}{|c|c|c|c|}
\hline \multirow{2}{*}{$\begin{array}{c}\text { Type of starter } \\
\text { cultures }\end{array}$} & \multicolumn{3}{|c|}{ Physicochemical characteristics } \\
\cline { 2 - 4 } & $\begin{array}{c}\text { Titratable } \\
\text { acidity } \\
\text { (\% lactic acid) }\end{array}$ & Viscosity (cp at 20 $\left.{ }^{\circ} \mathbf{C}\right)$ & $\begin{array}{c}\text { Diacetyl*** } \\
\text { production }\end{array}$ \\
\hline $\mathrm{S}_{1}$ & $0.69^{\mathrm{cd}}$ & $127.66^{\mathrm{b}}$ & - \\
\hline $\mathrm{S}_{2}$ & $0.72^{\mathrm{ab}}$ & $162.33^{\mathrm{a}}$ & - \\
\hline $\mathrm{S}_{3}$ & $0.67^{\mathrm{c}}$ & $104.00^{\mathrm{c}}$ & + \\
\hline $\mathrm{S}_{4}$ & $0.68^{\mathrm{cd}}$ & $102.86^{\mathrm{c}}$ & + \\
\hline $\mathrm{S}_{5}$ & $0.74^{\mathrm{a}}$ & $157.00^{\mathrm{a}}$ & - \\
\hline $\mathrm{S}_{6}$ & $0.68^{\mathrm{bc}}$ & $136.33^{\mathrm{b}}$ & + \\
\hline $\mathrm{S}_{7}$ & $0.70^{\mathrm{ab}}$ & $126.66^{\mathrm{b}}$ & + \\
\hline $\mathrm{SEm}$ & 0.01 & 4.82 & \\
\hline $\mathrm{CD}$ & 0.04 & 14.62 & \\
\hline $\mathrm{CV} \%$ & 3.55 & 6.38 & \\
\hline & & & \\
\hline
\end{tabular}


* $\mathrm{S}_{1}$ : Streptococcus thermophilus MTCC 5460

$\mathrm{S}_{2}$ : Lactobacillus helveticus MTCC 5463

$\mathrm{S}_{3}$ : Lactococcus lactis subspp. diacetylactis NCDC 60

$\mathrm{S}_{4}$ : Lactococcus lactis subspp. lactis NCDC 193

$\mathrm{S}_{5}$ : Streptococcus thermophilus MTCC 5460 and Lactobacillus helveticus MTCC 5463 (in 1:1 ratio)

$\mathrm{S}_{6}$ : Lactobacillus helveticus MTCC 5463and Lactococcus lactis subspp. diacetylactis NCDC 60 (in 1:1 ratio)

$\mathrm{S}_{7}$ : Lactobacillus helveticus MTCC 5463 and lactococcus lactis subspp. lactis NCDC 193 (in 1:1 ratio)

\# The values are mean of three replications

**The sign (+) indicates diacetyl production and (-) stands for absence of diacetyl compounds.

*** Values within columns (treatments) with same lowercase superscript did not differ significantly $(\mathrm{P}<0.05)$ from each other.

Table.5 Effect of addition of fermented paneer whey on sensory profile of cultured buttermilk

\begin{tabular}{|c|c|c|c|c|}
\hline \multirow{2}{*}{$\begin{array}{l}\text { Addition of } \\
\text { fermented } \\
\text { paneer whey }\end{array}$} & \multicolumn{4}{|c|}{ Sensory score } \\
\hline & Flavour & $\begin{array}{l}\text { Colour and } \\
\text { appearance }\end{array}$ & $\begin{array}{c}\text { Body and } \\
\text { texture }\end{array}$ & $\begin{array}{c}\text { Overall } \\
\text { acceptability }\end{array}$ \\
\hline $\mathrm{RT}_{1}(40: 60)$ & $6.74^{b}$ & 7.74 & $6.66^{\mathrm{b}}$ & $7.04^{\mathrm{b}}$ \\
\hline $\mathrm{RT}_{2}(\mathbf{5 0 : 5 0 )}$ & $6.78^{b}$ & 7.96 & $6.96^{b}$ & $7.23^{b}$ \\
\hline $\mathrm{RT}_{3}(60: 40)$ & $7.75^{\mathrm{a}}$ & 8.04 & $8.03^{\mathrm{a}}$ & $7.94^{\mathrm{a}}$ \\
\hline $\mathrm{RT}_{4}(\mathbf{7 0 : 3 0 )}$ & $8.12^{\mathrm{a}}$ & 8.13 & $8.34^{\mathrm{a}}$ & $8.19^{\mathrm{a}}$ \\
\hline $\mathbf{R T}_{5}$ & $6.89^{b}$ & 7.73 & $6.78^{b}$ & $7.13^{b}$ \\
\hline $\mathbf{R T}_{6}$ & $6.51^{b}$ & 7.57 & $6.54^{b}$ & $6.87^{b}$ \\
\hline SEm \pm & 0.23 & 0.19 & 0.25 & 0.17 \\
\hline CD & 0.68 & $\mathrm{NS}$ & 0.74 & 0.50 \\
\hline $\mathrm{CV} \%$ & 6.40 & 4.83 & 6.95 & 4.55 \\
\hline \multicolumn{5}{|c|}{$\begin{array}{l}* \text { First digit in the ratio stands for per cent of dahi and second digit for per cent of fermented } \\
\text { paneer whey on w/w basis. } \\
\text { RT }_{5} \text { : Control (dahi: water in } 70: 30 \mathrm{w} / \mathrm{w} \text { ratio) } \\
\mathrm{RT}_{6} \text { : Market sample } \\
\text { \#The values are mean of four replications. } \\
* * * \text { Values within columns (treatments) with same lowercase superscript did not differ } \\
\text { significantly }(\mathrm{P}<0.05) \text { from each other. }\end{array}$} \\
\hline
\end{tabular}


Table.6 Effect of addition of fermented paneer whey on physicochemical characteristics of cultured buttermilk

\begin{tabular}{|c|c|c|c|c|}
\hline \multirow{2}{*}{$\begin{array}{c}\text { Addition of } \\
\text { fermented } \\
\text { paneer whey }\end{array}$} & \multicolumn{4}{|c|}{ Physicochemical characteristics } \\
\hline & $\begin{array}{l}\text { Titratable acidity } \\
\text { (\% lactic acid) }\end{array}$ & $\begin{array}{c}\text { Total solids } \\
(\%)\end{array}$ & $\begin{array}{c}\text { Viscosity } \\
\left.\text { (cp at } 20^{\circ} \mathrm{C}\right)\end{array}$ & $\begin{array}{c}\text { Diacetyl } \\
\text { production } * *\end{array}$ \\
\hline $\mathrm{RT}_{1}(40: 60)$ & $0.73^{\mathrm{d}}$ & $5.94^{\mathrm{d}}$ & $22.45^{\mathrm{e}}$ & + \\
\hline RT2 (50:50) & $0.70^{\mathrm{c}}$ & $6.40^{c}$ & $40.50^{\mathrm{d}}$ & + \\
\hline RT3 (60:40) & $0.68^{b}$ & $6.97^{b}$ & $96.48^{\mathrm{b}}$ & + \\
\hline RT4 (70:30) & $0.68^{b}$ & $7.57^{\mathrm{a}}$ & $134.00^{\mathrm{a}}$ & + \\
\hline RT5 & $0.60^{\mathrm{a}}$ & $6.83^{b}$ & $66.90^{\mathrm{c}}$ & + \\
\hline RT6 & $0.61^{\mathrm{a}}$ & $6.50^{c}$ & $40.76^{\mathrm{d}}$ & - \\
\hline SEm \pm & 0.004 & 0.128 & 2.285 & \\
\hline CD & 0.01 & 0.38 & 7.04 & \\
\hline CV \% & 1.32 & 3.33 & 5.92 & \\
\hline \multicolumn{5}{|c|}{ 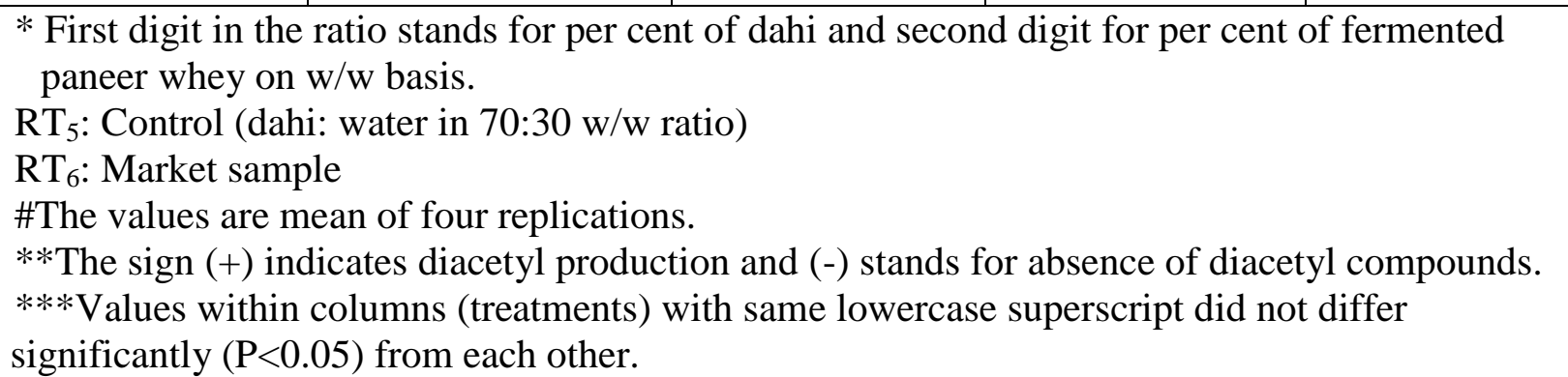 } \\
\hline
\end{tabular}

The physicochemical characteristics of buttermilk prepared by blending dahi with different proportions of fermented paneer whey are presented in Table 6.

From the data it can be seen that acidity of the cultured buttermilk increased continuously with increase in amount of paneer whey added and reached to a maximum level of 0.73 . On increase in rate of paneer whey addition from 30 to 60 per cent, acidity value of the cultured buttermilk increased significantly. The maximum acidity score of the cultured buttermilk was obtained on addition of paneer whey at the rate of 60 per cent and minimum for $\mathrm{RT}_{5}$. Lactobacillus helveticus MTCC 5463 is reported to grow well in whey and produce lactic acid rapidly. Diacetyl production test was positive in all samples of buttermilk analysed except the market sample $\mathrm{RT}_{6}$.
This is because the same combination and rate of cultures $L b$. helveticus MTCC 5463 and L. lactis subspp. diacetyl lactis NCDC 60 culture was used for preparation of cultured buttermilk except $\mathrm{RT}_{6}$.

$\mathrm{RT}_{4}$ had $\mathrm{TS}$ of 7.57 per cent, the highest among all experimental samples and it differed significantly $(\mathrm{P}<0.05)$ from others. Presence of more amount of dahi (70 per cent) in $\mathrm{RT}_{4}$ compared to other samples has contributed to its higher TS content. As the concentration of addition of whey increased from 30 to 60 per cent the TS decreased correspondingly from 7.57 to 5.94 per cent. But all buttermilk samples prepared by blending dahi and fermented whey in different proportions has more TS compared to control sample $\mathrm{RT}_{5}$ (6.83 per cent) and market sample $\mathrm{RT}_{6}$ (6.50 per cent). Because $\mathrm{RT}_{5}$ is prepared by blending dahi and water 
in 70: $30(\mathrm{w} / \mathrm{w})$ ratio. Similar is the case with market samples $\left(\mathrm{RT}_{5}\right)$ where buttermilk is prepared by conventional method of blending dahi and water. In case of $\mathrm{RT}_{1}$ more amounts of fermented paneer whey was added (60 per cent) that leads to the low TS content.

The trend in the viscosity of cultured buttermilk prepared by addition of different rate of fermented whey is in accordance with their corresponding $\mathrm{TS}$ content. $\mathrm{RT}_{4}$ with TS of 7.57 per cent gave maximum viscosity of $134 \mathrm{cp}$ at $20^{\circ} \mathrm{C}$ and differed significantly from all other samples. It is very clear from the Table 4.7 that as the TS increased viscosity also increased correspondingly.

In conclusion, from the different phase of this study, it was found that both $\mathrm{RT}_{3}$ (60 per cent dahi and 40 per cent fermented paneer whey) and $\mathrm{RT}_{4}$ (70 per cent dahi and 30 per cent fermented paneer whey) differed for their physicochemical characteristics like titratable acidity and viscosity. But values for titratable acidity and viscosity of both $\mathrm{RT}_{3}$ and $\mathrm{RT}_{4}$ were within the acceptable limit for a product like cultured buttermilk. The sensory characteristics of both $\mathrm{RT}_{3}$ and $\mathrm{RT}_{4}$ were significantly higher compared to other samples. Since the difference between $\mathrm{RT}_{3}$ and $\mathrm{RT}_{4}$ for sensory characteristics was non-significant, both these samples were acceptable. Thus, paneer whey can be successfully utilized for preparation of butter milk to the extent of 40 per cent is used for the preparation of cultured buttermilk with good diacetyl flavour.

\section{References}

Almeida, K.E., Tamime, A.Y. and Oliveira, M.N. 2008. Acidification rates of probiotic bacteria in Minas frescal cheese whey. $L W T, 41: 311-316$.
Almeida, K.E., Tamime, A.Y. and Oliveira, M.N. 2009. Influence of total solids contents of milk whey on the acidifying profile and viability of various lactic acid bacteria. LWT Food Sci. and Tech., 42: 672-678.

Alsaed, A.K. and Ahmed, R. 2010. Concentrating and drying of whey and utilization of the produced products in bakery and confectionery. A progress report, Department of Nutrition and Food Technology, Faculty of Agriculture, University of Jordan, Amman, Jordan.

Ayala-Hernandez, I., Goff, H.D., and Corredig, M. 2008. Interactions between milk proteins and exopolysaccharides produced by Lactococcus lactis observed by scanning electron microscopy. $J$. Dairy Sci., 91: 2583-2590.

Behare, P., Prajapati, J.B. and Singh, R. 2015. "Starter culture in milk fermentation "'- Fermented milk and dairy products (Edited by Kumar, P), New delhi.

Behare, P.V., Singh, R., Kumar, M., Prajapati, J.B., and Singh, R.P. 2009. Exopolysaccharides of lactic acid bacteria: A review. J. Food Sci. Technol., 46: 1-11.

Bureau of Indian Standards Handbook (BIS: Part XI, 1981. Handbook of Food analysis, Dairy Products. Indian Standards Institution, Manak Bhavan, New Delhi.

Conway, V., Gauthier, S. F, and Pouliot, Y. 2014. Buttermilk: Much more than a source of milk phospholipids. Animal Frontiers, 4: 44-51.

Conway, V., Gauthier, S. F., and Pouliot, Y. 2013. Antioxidant activities of buttermilk proteins, whey proteins, and their enzymatic hydroly sates. $J$. Agricul. and Food Chem., 61: 64-72.

$\mathrm{Fu}$, S., Shen, Z., Ajlouni, S., Ng, K., 
Sanguansri, L., and Augustin, M.A. 2014. Interactions of buttermilk with curcuminoids. Food Chem., 149: 4753.

Fuller, K.L., Kuhlenschmidt, T.B., Kuhlenschmidt, M.S., Jiménez-Flores, R., and Donovan, S.M. 2013. Milk fat globule membrane isolated from buttermilk or whey cream and their lipid components inhibit infectivity of rotavirus in vitro. J. Dairy Sci., 96(6): 3488-3497.

Gallardo-Escamilla, F.J., Kelly, A.L. and Delahunty, C.M. 2005. Sensory Characteristics and Related Volatile Flavor Compound Profiles of Different Types of Whey, J. Dairy Sci., 88: 2689-2699.

Hassan, A.N. 2008. ADSA Foundation Scholar Award: possibilities and challenges of exopolysaccharideproducing lactic cultures in dairy foods. J. Dairy Sci., 91: 1282-1298.

Jinarak, S., Olabi, A., Jimenez, R., Sodini, I. and Walker, J. 2005. Sensory evaluation of whey and sweet cream buttermilk. J. Dairy Sci., 89: 24412450

Jolly, L., Vincent, S. J. F., Duboc, P., and Neeser, J.R. 2002. Exploiting exopolysaccharides from lactic acid bacteria. Antonie van Leeuwenhoek 82: 367-374.

Landge, S.N. and Gaikwad, S.M. 2013. Studies on preparation and sensory evaluation of whey beverage. Int. J. Food Agril. and Vet. Sci., 3: 27-29.

Larsson, S.C., Andersson, S.O., Johansson, J. ., and Wolk, A. 2008. Cultured milk, yogurt, and dairy intake in relation to bladder cancer risk in a prospective study of Swedish women and men. American J. Clin. Nutri., 88: 10831087.

Maheta, R., Balakrishnan, S., and Aparnathi, K.D. 2015. Standardization of the method for utilization of paneer whey in cultured buttermilk. J. Food Sci. and Technol., doi:10.1007/s13197014-1301-2.

Mollea, C., Marmo, L., and Bosco, F. 2013. Valorisation of cheese whey, a byproduct from the dairy industry. In: Food Industry, ed. I. Muzzalupo, 54988. Rijeka, Croatia: InTech.

Oliveira, M.N., Almeida, K.E., Damin, M.R., Rochat, T., Gratadoux, J.J., Miyoshi, A., Langella, P., and Azevedo, V. 2009. Behavior and viability of spontaneous oxidative stress-resistant Lactococcus lactis mutants in experimental fermented milk processing. Genetics and Mol. Res., 8(3): 840-847.

Oliviera, M.N. \& Damin, M. R. 2003. Effect of starter cultures on acidification properties of the fermented product. Genetics and Mol. Res., 23: 172-176.

Pal, D. and Raju, N. 2008. Application of buttermilk in the manufacture of value added dairy products.Cource compendium-Technological advances in utilization of dairy byproducts, NDRI, Karnal.

Patidar, S.K. and Prajapati, J.B. 1998. Standardization and evaluation of lassi prepared using $L b$. acidophilus and Str. thermophilus. J. Food Sci. Technol., 35: 428 - 431.

Pescumaa, M., Heberta, E.M., Mozzia, F., de Valdez. G.F. 2008. Whey fermentation by thermophilic lactic acid bacteria: Evolution of carbohydrates and protein content. Food Microbiol., 25: 442-451.

Pogačić, T., Mancini, A., Santarelli, M., Bottari, B., Lazzi, C., Neviani, E., and Gatti, M. 2013. Diversity and dynamic of lactic acid bacteria strains during aging of a long ripened hard cheese produced from raw milk and undefined natural starter. Food 
Microbiol., 36(2): 207-215.

Prado, F.C., Parada, J.L., Pandey, A. and Soccol, C.R. 2008. Review: Trends in non-dairy probiotic beverages. Food Res. Int., 41: 111-123.

Shah, N. 2003. Bifidobacterium spp.: Applications in fermented milks. Pages 147-149 in Encyclopedia of Dairy Sciences. H. Roginski, J. W. Fuquay, and P. F. Fox, ed. Academic Press, London, UK.

Shukla, F.C., Sharma, A. and Bakshi, A.K. 2004. Studies on the preparation of fruit juice beverages using milk byproducts. In: Souvenir, International Conference on Processed Foods for 21st Century, January 14-16, 2000,
Calcutta, India. Abst. No. FPEXXVIII/B.

Steel, R.G.D. and Torrie, J.H. 1980. Principles and Procedures of Statistics-a Biometrical Approach, 2nd edn, New York: McGraw-Hill. 137167.

Walstra, P., Wouters, J.T.M. and Geurts, T.J. 2005. Fermented milks- In Dairy Science and Technology, Second Edition, CRC Press, New York. pp551-569.

Yadav, J.S., Grover, S. and Batish, V.K. 1993. A Comprehensive Dairy Microbiology. Metropolitan Book Co pvt. Ltd. New Delhi.

\section{How to cite this article:}

Sonali L. Parekh, Smitha Balakrishnan and K.D. Aparnathi. 2016. Sensory Attributes and Physicochemical Characteristics of Cultured Buttermilk prepared by Partial Substitution of Milk with Paneer Whey. Int.J.Curr.Microbiol.App.Sci. 5(12): 333-348.

doi: http://dx.doi.org/10.20546/ijcmas.2016.512.036 